\title{
Antral follicles population in heifers and cows of Nelore and Girolando breeds
}

\section{População de folículos antrais em vacas e novilhas da raça Nelore e Girolando}

\author{
Jair Sábio de Oliveira Junior ${ }^{1}$; Christopher Junior Tavares Cardoso ${ }^{1}$; \\ Wilian Aparecido Leite da Silva ${ }^{1}$; Henrique Kischel ${ }^{2}$; Mirela Brochado Souza ${ }^{3}$; \\ Evelyn Rabelo Andrade ${ }^{4}$; Eriklis Nogueira ${ }^{5}$; Katia Cristina Silva-Santos ${ }^{6}$; \\ Marcelo Marcondes Seneda ${ }^{7}$; Fabiana de Andrade Melo-Sterza ${ }^{8 *}$
}

\begin{abstract}
The aim of this study was to evaluate ovarian antral follicle populations (OAFP) of Nelore and Girolando breed heifers (12-18 months old) and cows (24-60 months old). Animals were assigned to four groups: (1) Nelore cows ( $\mathrm{n}=18)$, (2) Girolando cows $(\mathrm{n}=20),(3)$ Nelore heifers $(\mathrm{n}=7)$, and (4) Girolando heifers $(n=7)$. Cows were treated to synchronize follicular wave emergence by implantation of an intravaginal device containing $1.9 \mathrm{~g}$ of progesterone, as well as intramuscular administration of $2 \mathrm{mg}$ of estradiol benzoate and $25 \mathrm{mg}$ of dinoprost. This synchronization treatment was administered at a random day of the estrous cycle of each cow, designated D0. Intravaginal devices were removed on D7, and on D11, OAFP counts were performed by transvaginal ovarian ultrasound. For each cow, all follicles $\geq 3 \mathrm{~mm}$ in diameter were counted in both ovaries and counts were performed three times at 35-day intervals. Counts were also obtained from heifers, but these animals were not treated for synchronization of follicular wave emergence. Analysis of variance (ANOVA) with Tukey's test and Pearson's correlation test were used to compare mean OAFPs between counts as well as mean OAFPs between breed and age groups. No differences were observed in mean OAFPs between Nelore and Girolando cows ( 30.9 vs. 26.7, respectively; $\mathrm{P}>0.05$ ) or heifers (16.2 vs. 18.1, respectively; $\mathrm{P}>0.05$ ). However, within each breed, there were differences in mean OAFPs between heifers and cows (for Nelore cattle: 16.2 and 30.9, respectively; for Girolando cattle: 18.1 and 26.7, respectively; both P < 0.05). In conclusion, OAFPs were similar between Nelore and Girolando breeds and were influenced by age. Furthermore, we observed a high correlation for individual animals between the mean numbers of follicles counted in both ovaries and total number of follicles counted in either the right or left ovary, indicating that the evaluation of a single ovary is sufficient to estimate the OAFP of an individual.
\end{abstract}

Key words: Ovary, ultrasonography, bovine

1 Discentes do curso de Mestrado, Programa de Pós-graduação em Zootecnia, Universidade Estadual de Mato Grosso do Sul, UEMS, Aquidauana, MS, Brasil.E-mail: jairvt@uol.com.br; christopherjtc@hotmail.com; wilian.leite@live.com

2 Discente do curso de Zootecnia, UEMS, Aquidauana, MS, Brasil. E-mail: kischel.henrique@gmail.com

3 Discente do curso de Doutorado, Programa de Pós-graduação em Ciência Animal, Universidade Estadual de Londrina, UEL, Londrna, PR, Brasil. E-mail: mirela.mbs@gmail.com

4 Prof ${ }^{a} \mathrm{Dr}^{\mathrm{a}}$, curso de graduação em Medicina Veterinária, Universidade Federal de Rondônia, UNIR, Rolim de Moura, RO, Brasil. E-mail: evelyn_andrade@yahoo.com

5 Pesquisador A do Centro de Pesquisa Agropecuária do Pantanal, CPAP, Empresa Brasileira de Pesquisa Agropecuária, EMBRAPA, Corumbá, MS, Brasil. E-mail: eriklis.nogueira@embrapa.br

6 Prof ${ }^{a}$ Dra $^{\mathrm{a}}$, Curso de Graduação em Medicina Veterinária, Centro Universitário Filadélfia, UNIFIL, Londrina, PR, Brasil. Email: kati_cris@hotmail.com

7 Prof. Dr., Programa de Pós-Graduação em Ciência Animal, UEL, PR, Brasil. E-mail: mseneda@uel.br

8 Prof $^{\mathrm{a}}$ Dra $^{\mathrm{a}}$, Programa de Pós-Graduação em Zootecnia, UEMS, Aquidauana, MS, Brasil. E-mail: fabiana.sterza@uems.br

* Author for correspondence 


\title{
Resumo
}

\begin{abstract}
Este estudo objetivou avaliar a população folicular antral ovariana (PFAO) de novilhas (12 a 18 meses) e vacas (24 a 60 meses) das raças Nelore e Girolando. Os animais foram divididos em quatro grupos: 1) vacas Nelore $(n=18) ; 2)$ vacas Girolando $(n=20) ; 3)$ Novilhas Nelore $(n=7)$ e; 4) Novilhas Girolando $(\mathrm{n}=7)$. Nos grupos das vacas, os animais receberam um dispositivo intravaginal com $1.9 \mathrm{~g}$ de progesterona, $2 \mathrm{mg}$ de benzoato de estradiol IM e $25 \mathrm{mg}$ de dinoprost IM, em um dia aleatório do ciclo estral (D0). No D7 o dispositivo de progesterona foi retirado. Os animais foram submetidos à ultrassonografia ovariana via transvaginal para contagem da PFAO no D11. Foram contados todos os folículos $\geq 3 \mathrm{~mm}$ de diâmetro em ambos os ovários. O procedimento de contagem da PFAO foi repetido três vezes, com intervalos de 35 dias entre as repetições. Para os grupos de novilhas foram adotados os mesmos procedimentos descritos acima, porém estes animais não receberam o tratamento de sincronização da emergência da onda folicular. Para avaliação da PFAO entre as contagens e da média das contagens entre as raças e os grupos, foi realizada análise de variância (ANOVA) seguida de Teste de Tukey a 5\% de probabilidade e correlação de Pearson, através do programa SAS, utilizando o Proc GLIMMIX. Não foi observada diferença significativa $(\mathrm{p}>0.05)$ entre as médias das contagens da PFAO de vacas Nelore e Girolando (30.9 e 26.7, respectivamente) e das novilhas Nelore e Girolando (16.2 e 18.1, respectivamente). Porém, diferença significativa $(\mathrm{p}<0.05)$ da PFAO entre as categorias de novilhas e vacas da raça Nelore (16.2 e 30.9, respectivamente) e Girolando (18.1 e 26.7, respectivamente) foi observada. Com base nestes dados, conclui-se que a PFAO em fêmeas bovinas das raças Nelore e Girolando é semelhante e influenciada pela idade. Além disso, considerando a alta correlação observada entre a média de folículos dos dois ovários e a média de folículos dos ovários esquerdo e direito separadamente, sugere-se que a avaliação de um único ovário é suficiente para estimar a PFAO do indivíduo.
\end{abstract}

Palavras-chave: Bovinos, folículos antrais, ultrassonografia

\section{Introduction}

Girolando is a hybrid of Gir and Holstein breeds, combining the hardiness of Bos taurus indicus to the high productivity of Bos taurus taurus. Girolando was officially recognized as a breed by the Brazilian Agriculture Ministry relatively recently, in 1996, which explains the lack of information on reproductive physiology for this breed (SANTOS FILHO et al., 2001).

There are increasing attempts to improve bovine production through the development and application of reproductive biotechnologies that increase reproductive efficiency. Within the last five decades, a negative association between high production and fertility has been observed mainly in dairy cattle (SARTORI et al., 2010; WALSH et al., 2011), and there have been attempts to better understand and reduce this association. A low population of ovarian antral follicles has been associated with certain characteristics of reduced fertility, including smaller ovaries and low numbers of ovarian antral follicles and oocytes (IRELAND et al., 2008), low rates of pregnancy at the end of the breeding season (MOSSA et al., 2012), diminished responsiveness to superovulation (SINGH et al., 2004; IRELAND et al., 2007), reduced progesterone and antiMüllerian hormone concentrations (IRELAND et al., 2008; JIMENEZ-KRASSEL et al., 2009), and diminished endometrial thickness between days 0 and 6 of the estrus cycle (JIMENEZ-KRASSEL et al., 2009). Therefore, the reproductive potential of bovine females can be correlated to the ovarian antral follicle population - OAFP (IRELAND et al., 2008; EVANS et al., 2010; IRELAND et al., 2011; MOSSA et al., 2012) and this parameter could be considered as an auxiliary tool for selection of cattle with high reproductive efficiency.

An easy and reliable method for the selection of animals with high reproductive efficiency would contribute to improved livestock productivity. Considerable information on production performance of Bos taurus taurus and Bos taurus indicus animals is available, but little is known about crossbred cattle. Because good milk production can 
be achieved at lower cost by using crossbred animals, a better understanding of the physiology and genetic selection of these cross breeds is necessary. This study is a complement to reported data for purebred cattle. Our aim was to evaluate OAFPs in Nelore and Girolando cattle using transvaginal ultrasonography and to compare OAFP values between breeds and age groups. The relationship between OAFP values from the right and left ovary in individual animals was also evaluated.

\section{Materials and Methods}

\section{Animals}

Healthy, non-pregnant, non-lactating female cattle with an average body condition score between 2.5 and 3.5 (5-point scale) were used. Animals were maintained on pasture (Brachiaria brizantha and Panicum maximum) and provided with water and mineral salt ad libitum. The property where animals were held was located in the Alto Pantanal region of Mato Grosso do Sul State, Brazil (-20 28' $16^{\prime \prime}$ latitude; $-55^{\circ} 47^{\prime} 14^{\prime \prime}$ longitude; $147 \mathrm{~m}$ above sea level). For the period of the study, ambient temperature varied between $19^{\circ} \mathrm{C}$ and $37^{\circ} \mathrm{C}$, relative air humidity was between $22 \%$ and $95 \%$, and total rainfall was $267 \mathrm{~mm}$ (INMET, 2013). Cattle were assigned to four groups: (1) Nelore (Bos indicus) cows ( $\mathrm{n}=18)$, (2) Girolando (Bos taurus indicus $1 / 4$ $\times$ Bos taurus taurus $3 / 4)$ cows $(\mathrm{n}=20),(3)$ Nelore heifers $(n=7)$, and (4) Girolando heifers $(n=7)$. All cows were between 24 and 60 months old and all heifers, between 12 and 18 months old during the experimental period. All cows were post-pubertal, cyclical, and non-lactating and had no contact with bulls. Heifers were probably pre-pubertal, based on evaluation of ovary characteristics and consideration of animal age.

\section{Experimental protocol}

Cows were treated to achieve synchronization of follicular wave emergence (Figure 1) at a random day in the estrus cycle, designated D0 of the study. Cows were implanted with an intravaginal device containing $1.9 \mathrm{~g}$ of progesterone (DP4CIDR ${ }^{\circledR}$, InterAg, Hamilton, New Zealand) and injected with estradiol benzoate (2 mg; EBESTROGIN®, Farmavet, Brazil) and dinoprost (25 mg; LUTALYSE®, Zoetis, São Paulo, Brazil), both intramuscularly. On D7, intravaginal devices were removed and on D11, OAFP counts were performed. Before each OAFP count, feces were removed from the rectum and the perineal area cleaned with tap water and $70 \%$ ethanol. The ovaries of each animal were visualized using a 7.5-convex intravaginal array transducer (Aquila PRO®, Pie Medical, Maastricht, The Netherlands), and the total number of antral follicles $\geq 3 \mathrm{~mm}$ in diameter was recorded. Counts were recorded from each animal three times at 35 day intervals.

Figure 1. Protocol for synchronization of follicular wave emergence prior to OAFP counting in cows.

\begin{tabular}{|c|c|c|c|c|}
\hline D0* & D7* & D11 & D46 & D81 \\
\hline +DP4 & & $1^{\mathrm{a}}$ & $2^{\mathrm{a}}$ & $3^{\mathrm{a}}$ \\
EB & $-\mathrm{DP} 4$ & OAFP & OAFP & OAFP \\
Dinoprost & & $1^{\text {st }}$ count & $2^{\text {nd }}$ count & $3^{\text {rd }}$ count \\
\hline
\end{tabular}

* Heifers did not receive this treatment; DP4 intravaginal progesterone device implanted (+) and removed (-); EB, estradiol benzoate; OAFP, Ovarian Antral Follicle Population. 
Counts were taken from heifers as described above, except that in order to avoid early cycle induction in pre-pubertal animals, synchronization of follicular development was not carried out. The timing of the first count in relation to each animal's stage of ovarian follicular development was therefore random for heifers.

\section{Statistical analysis}

Ovarian antral follicle population values between counting events, as well as mean OAFPs between breed and age groups, were compared using an Analysis of variance (ANOVA) test with Tukey's post-hoc test and Pearson's correlation test. Tests were carried out at a level of significance of $5 \%$, using SAS (SAS Institute Inc., Cary, NC, USA) with Proc GLIMMIX software.

\section{Results}

Mean OAFP counts for cows and heifers of each breed are presented in Table 2. Counts were performed three times for each individual animal and repeatability in counts was observed, with a positive correlation between counts regardless of cattle breed or age $(\mathrm{P}<0.05$; Table 1$)$.

No influence of breed on OAFPs was observed, with mean OAFP values similar between Nelore and Girolando cattle $(\mathrm{P}=0.632$; Table 2$)$. However, within each breed, differences in the mean OAFPs were observed between heifers and cows $(\mathrm{P}<0.001$ for both breeds; Table 2).

A high correlation was observed between the mean number of follicles counted from both ovaries and the total number of follicles counted in either the right or left ovary of an individual animal (Table 3).

Table 1. Correlation of mean OAFPs between counts, regardless of breed and age.

\begin{tabular}{cccc}
\hline & FP $1 \times$ FP 2 & FP $1 \times$ FP 3 & FP $2 \times$ FP 3 \\
\hline Follicles Population Means & $27.60 \times 26.08$ & $27.60 \times 22.96$ & $26.08 \times 22.96$ \\
Correlation & 0.54 & 0.55 & 0.48 \\
Significance & $(\mathrm{n}=47)$ & $(\mathrm{n}=51)$ & $(\mathrm{n}=48)$ \\
& $<0.0001$ & $<0.0001$ & 0.0005 \\
\hline
\end{tabular}

FP 1, mean OAFP at first count; FP 2, mean OAFP at second count; FP 3, mean OAFP at third count.

Table 2. Adjusted mean OAFPs of cows and heifers (Nelore and Girolando breeds).

\begin{tabular}{cccc}
\hline Groups & Breed & Adjusted Mean & Standard Error \\
\hline $\begin{array}{c}\text { Cows } \\
(\mathrm{n}=20)\end{array}$ & Girolando & $26.7 \mathrm{a}$ & 1.7 \\
$\begin{array}{c}\text { Cows } \\
(\mathrm{n}=18)\end{array}$ & Nelore & $30.9 \mathrm{a}$ & 1.8 \\
$\begin{array}{c}\text { Heifers } \\
(\mathrm{n}=7)\end{array}$ & Girolando & $18.1 \mathrm{~b}$ & 2.8 \\
$\begin{array}{c}\text { Heifers } \\
(\mathrm{n}=7)\end{array}$ & Nelore & $16.2 \mathrm{~b}$ & 2.8 \\
\hline
\end{tabular}

a,b in the same column differ significantly $(\mathrm{P}<0.05)$, Tukey's test. 
Table 3. Correlation between the mean antral follicle population of the pair of ovaries and antral follicle population in the left or right ovary at each evaluation.

\begin{tabular}{ccccccc}
\hline & LO1 & LO2 & LO3 & RO1 & RO2 & RO3 \\
\hline Mean OAFP & 13.96 & 12.47 & 11.69 & 13.64 & 13.60 & 11.26 \\
Correlation & 0.85787 & 0.80757 & 0.74665 & 0.79060 & 0.68977 & 0.56853 \\
Significance & $<0.0001$ & $<0.0001$ & $<0.0001$ & $<0.0001$ & $<0.0001$ & $<0.0001$ \\
\hline
\end{tabular}

LO1, mean OAFP in the first count of the left ovary (LO); LO2, mean OAFP in the second count of the left ovary; LO3, mean OAFP in the third count of the left ovary; RO1, mean OAFP in the first count of the right ovary; RO2, mean OAFP in the second count of the right ovary; RO3, mean OAFP in the third count of the right ovary; Mean Fol - mean OAFP for the pair of ovaries from all three counts.

\section{Discussion}

The evaluation of OAFPs is an excellent tool for assisted reproductive programs (ART) in women and increases the accuracy of predicting high responsiveness of patients undergoing follicle stimulating hormone (FSH) treatment. For cattle, improved success of in vitro embryo production has been associated with high numbers of recovered cumulus oophorus complexes (COCs) from bovine females (PONTES et al., 2011; SILVA-SANTOS et al., 2014a, 2014b). However, high individual and between-breed variations in oocyte production have been observed and researchers seek to identify mechanisms underlying such variability.

The estrus cycles of the cows were synchronized prior to the first OAFP count so that the study was initiated with all cows at the same stage of follicular development. Subsequent counts were performed twice at 35-day intervals without synchronization and in accordance with other studies (CUSHMAN et al., 2009; SILVA-SANTOS et al, 2014a), no influence of stage of estrous cycle on OAFPs was observed. However, based on consideration of ovary characteristics as well as the historical age at puberty for Girolando and Nelore breeds in the study region, heifers were considered to be prepubertal at the time of the study and were therefore not subjected to the estrus synchronization treatment administered to cows. This was done to avoid early ovarian cycle induction of heifers and resulted in evaluations of OAFPs in heifers at random time points relative to the stage of ovarian development for each individual animal. We demonstrated a high within-breed correlation between OAFP counts carried out at different time points (Table 1 ), in accordance with previous reports for Nelore and Braford cattle (SILVA-SANTOS et al., 2014a, 2014b). We therefore conclude that a single count of antral follicles at a random day during the estrus cycle can be used to predict the OAFP of Girolando cattle and to select individuals for breeding based on this characteristic.

Approximately 24 antral follicles emerge at each new follicular wave for Bos taurus taurus breeds (GINTHER et al., 1996). In a study that evaluated the first follicular growth wave in Bos indicus, a great number of follicles (around 50) was reported (BURATINI JUNIOR et al., 2000); in another study, 30-50 follicles have been recorded in Bos indicus (LOUREIRO et al., 2012). A previous study reported higher numbers of small follicles developing during a wave emergence in Bos taurus indicus (33.4 \pm 3.2 follicles) compared to Bos taurus taurus cattle $(25.4 \pm 2.5$ follicles; CARVALHO et al., 2008). Higher OAFPs in Bos taurus indicus cattle could be associated with higher plasma levels of insulin-like growth factor (IGF)-I and free insulin, which are responsible for increased granulosa cell sensitivity to FSH, and the promotion of follicular recruitment (ALVAREZ et al., 2000).

Historically, there is high variation in OAFPs of cattle from different farms and different country regions. This variation is probably related to unintentional bias in selection of animals with high 
or low OAFPs in particular studies. In the present study, OAFPs of Nelore (Bos taurus indicus) and Girolando (Bos taurus taurus $3 / 4 \times$ Bos taurus indicus $1 / 4$ ) cattle were comparable between the two breeds for both cows and heifers under the same environmental conditions. In a large-scale in vitro embryo production program, recovery of 20.4 COCs per ovum pick-up (OPU) for 3/4 Girolando cattle (Bos taurus taurus $3 / 4 \times$ Bos taurus indicus $1 / 4$ ) and 31.4 COCs per OPU for $1 / 2$ Girolando females (Bos taurus taurus $1 / 2 \times$ Bos taurus indicus $1 / 2$ ) were reported (PONTES et al., 2010). These same authors also reported an average of 30.8 COCs for Nelore females (PONTES et al., 2011). These values are in agreement with those obtained from our study, considering that OAFP is strictly related to COC production.

The present study evaluated the influence of age on OAFPs for Nelore and Girolando breed cattle. Heifers were 12-18 months old (or 48-72 weeks) during the study period and had significantly different mean OAFPs when compared to cows of the same breed (Table 2). A significant increase in the number of follicles $\geq 3 \mathrm{~mm}$ in diameter in cattle of age 6-60 weeks has been described for beef heifers (HONARAMOOZ et al., 2004). Ovarian antral follicles develop in a wave-like fashion in calves as early as 2 weeks of age and this pattern resembles that seen in adult cattle. Serum concentrations of LH and FSH are high in cattle between 2 and 14 weeks of age, when numbers of ovarian follicles and maximum diameters of follicles are also observed to increase (EVANS et al., 1994a). In one study, no dramatic changes in follicle growth or in endocrine mechanisms controlling follicle growth were observed during the late pre-pubertal period, at the time of first ovulation, or in pubertal cattle (EVANS et al., 1994b). Marked growth of the reproductive tract observed in cattle within the first few months of age and prior to first ovulation reflects phases of increased ovarian follicle numbers and size (HONARAMOOZ et al., 2004). For beef heifers and cows, OAFPs have been correlated to birth weight and to age with an increased number of antral follicles observed until 5 years of age, following which decreasing OAFPs are seen (CUSHMAN et al., 2009). These reports are in accordance with our observation of differences in OAFPs between Nelore heifers (16.2 follicles) and cows (30.9 follicles), and between Girolando heifers (18.1 follicles) and cows (26.7 follicles), confirming an increase in OAFPs in cattle of these breeds between the ages of 12 and 60 months (Table 2). However, different results have been observed in Braford cattle, which show similar OAFPs from weaning to yearling ages in females with either high or low OAFPs, (SILVA-SANTOS et al., 2014a) as well as in Holstein cows and heifers (BURNS et al., 2005). It is know that OAFP is established under the influence of several factors, including concentrations of circulating insulin, insulin-like growth factor I, and anti-Müllerian hormone (ALVAREZ et al., 2000; SATRAPA et al., 2013; BATISTA et al., 2014). Suppression of serum insulin-like growth factor I (IGFI) can be induced by active immunization against growth hormonereleasing factor or by chronic nutritional restriction, with consequential alterations in $\mathrm{FSH}, \mathrm{LH}$, and estradiol serum concentrations. This results in changes in numbers and mean diameter of ovarian antral follicles and culminates in delayed puberty in heifers (SCHOPPEE et al, 1996). In consideration of these points endocrine mechanisms, environment conditions, individual variability, or a combination of these factors, could explain discrepancies observed between different studies as outlined above.

In the present study, we observed a high correlation between the mean number of antral follicles based on counts of both ovaries, and the number of antral follicles for each ovary - left or right (Table 3). Estimation of OAFPs using the weight of the ovary contralateral to that bearing the corpus luteum (CL) has been described in heifers (MURASAWA et al., 2005). In our study, although the presence of the CL was not evaluated, the strong positive relationship in the number of antral follicles 
between left and right ovaries is in agreement with previous work by Erickson (1966) and Cushman et al. (2009). Based on this, we propose that an OAFP value can be determined for an individual by ultrasound evaluation of a single ovary. This is an important finding for the application of OAFP counts in the field, as single-ovary counts will reduce the time taken for ultrasonography of each animal, improving efficiency and reducing the welfare impact of prolonged restraint on individual animals.

\section{Conclusion}

In summary, OAFPs of Nelore and Girolando were found to be positively correlated between counts within each breed, suggesting that one ovarian ultrasound evaluation is adequate to evaluate OAFPs of cattle. Mean OAFPs were similar between Nelore and Girolando cattle and in both breeds were influenced by animal age, with lower OAFPs observed in heifers. Furthermore, the OAFP of a single ovary can be used to determine the OAFP of each individual, improving the practicality of this technique for use in the field.

\section{References}

ALVAREZ, P.; SPICER, L. J.; CHASE JUNIOR, C. C.; PAYTON, M. E.; HAMILTON, T. D.; STEWART, R. E.; HAMMOND, A. C.; OLSON, T. A.; WETTEMANN, R. P. Ovarian and endocrine characteristics during an estrous cycle in Angus, Brahman, and Senepol cows in a subtropical environment. Journal of Animal Science, Champaign, v. 78, n. 5, p. 1291-1302, may 2000.

BATISTA, E. O. S.; MACEDO, G. G.; SALA, R. V.; ORTOLAN, M. D. D. V.; SÁFILHO, M. F.; DEL VALLE, T. A.; JESUS, E. F.; LOPES, R. N. V. R.; RENNÓ, F. P.; BARUSELLI, P. S. Plasma antimullerian hormone as a predictor of ovarian antral follicular population in Bos indicus (Nelore) and Bos taurus (Holstein) heifers. Reproduction in Domestic Animals, Berlim, v. 49, n. 3, p. 448-452, apr. 2014.
BURATINI JUNIOR, J.; PRICE, C. A.; VISINTIN, J. A.; BO, G. A. Effects of dominant follicle aspiration and treatment with recombinant bovine somatotropin (BST) on ovarian follicular development in nelore (Bos indicus) heifers. Theriogenology, Stoneham, v. 54, n. 3, p. 421431, aug. 2000.

BURNS, D. S.; JIMENEZ-KRASSEL, F.; IRELAND, J. L. H.; KNIGHT, P. G.; IRELAND, J. J. Numbers of antral follicles during follicular waves in cattle: evidence for high variation among animals, very high repeatability in individuals, and an inverse association with serum follicle-stimulating hormone concentrations. Biology of Reproduction, New York, v. 73, n. 1, p. 54-62, mar. 2005

CARVAlHO, J. B.; CARVALHO, N. A.; REIS, E. L.; NICHI, M.; SOUZA, A. H.; BARUSELLI, P. S. Effect of early luteolysis in progesterone-based timed AI protocols in Bos indicus, Bos indicus x Bos taurus, and Bos taurus heifers. Theriogenology, Stoneham, v. 69, n. 2, p. 167175, 15 jan. 2008.

CUSHMAN, R. A.; ALLAN, M. F.; KUEHN, L. A.; SNELlinG, W. M.; CUPP, A. S.; FREETLY, H. C. Evaluation of antral follicle count and ovarian morphology in crossbred beef cows: investigation of influence of stage of the estrous cycle, age, and birth weight. Journal of Animal Science, Champaign, v. 87, n. 6, p. 1971-1980, jun. 2009.

ERICKSON, B. H. Development and senescense of the postnatal bovine ovary. Jounal of Animal Science, Savoy, v. 25, n. 3, p. 800-805, aug. 1966.

EVANS, A. C.; MOSSA, F.; FAIR, T.; LONERGAN, P.; BUTLER, S. T.; ZIELAK-STECIWKO, A. E.; SMITH, G. W.; JIMENEZ-KRASSEL, F.; FOLGER, J. K.; IRELAND, J. L.; IRELAND, J. J. Causes and consequences of the variation in the number of ovarian follicles in cattle. Society for Reproduction and Fertility Supplement, Colchester, v. 67, n. 1, p. 421-429, 2010.

EVANS, A. C. O.; ADAMS, G. P.; RAWLINGS, N. C. Endocrine and ovarian follicular changes leading up to the first ovulation in prepubertal heifers. Journal of Reproduction and Fertility, Cambridge, v. 100, p. 187194, mar. 1994a.

Follicular and hormonal development in prepubertal heifers from 2 to 36 weeks of age. Journal of Reproduction and Fertility, Cambridge, v. 102, p. 463470, jun. 1994b.

GINTHER, O. J.; WILTBANK, M. C.; FRICKE, P. M.; GIBBONS, J. R.; KOT, K. Selection of the dominant follicle in cattle. Biology of Reproduction, New York, v. 55, n. 6, p. 1187-1194, dec. 1996. 
HONARAMOOZ, A.; ARAVINDAKSHAN, J.; CHANDOLIA, R. K.; BEARD, A. P.; BARTLEWSKI, P. M.; PIERSON, R. A.; RAWLINGS, N. C. Ultrasonographic evaluation of the pre-pubertal development of the reproductive tract in beef heifers. Animal Reproduction Science, Amsterdam, v. 80, n. 1-2, p. 15-29, jan. 2004.

INSTITUTO NACIONAL DE METEOROLOGIA INMET. Aquidauana: IMET, 2013. Disponível em: $<$ http://www.inmet.gov.br/portal/index.php?r=home2/ index>. Acesso em: 12 dez. 2013.

IRELAND, J. J.; SMITH, G. W.; SCHEETZ, D.; JIMENEZ-KRASSEL, F.; FOLGER, J. K.; IRELAND, J. L.; MOSSA, F.; LONERGAN, P.; EVANS, A. C. Does size matter in females? An overview of the impact of the high variation in the ovarian reserve on ovarian function and fertility, utility of anti-Mullerian hormone as a diagnostic marker for fertility and causes of variation in the ovarian reserve in cattle. Reproduction, Fertility and Development, East Melbourne, v. 23, n. 1, p. 1-14, 2011.

IRELAND, J. J.; WARD, F.; JIMENEZ-KRASSEL, F.; IRELAND, J. L.; SMITH, G. W.; LONERGAN, P.; EVANS, A. C. Follicle numbers are highly repeatable within individual animals but are inversely correlated with FSH concentrations and the proportion of goodquality embryos after ovarian stimulation in cattle. Human Reproduction, Oxford, v. 22, n. 6, p. 1687-1695, jun. 2007.

IRELAND, J. L.; SCHEETZ, D.; JIMENEZ-KRASSEL, F.; THEMMEN, A. P.; WARD, F.; LONERGAN, P.; SMITH, G. W.; PEREZ, G. I.; EVANS, A. C.; IRELAND, J. J. Antral follicle count reliably predicts number of morphologically healthy oocytes and follicles in ovaries of young adult cattle. Biology of Reproduction, New York, v. 79, n. 6, p. 1219-1225, dec. 2008.

JIMENEZ-KRASSEL, F.; FOLGER, J. K.; IRELAND, J. L.; SMITH, G. W.; HOU, X.; DAVIS, J. S.; LONERGAN, P.; EVANS, A. C.; IRELAND, J. J. Evidence that high variation in ovarian reserves of healthy young adults has a negative impact on the corpus luteum and endometrium during estrous cycles in cattle. Biology of Reproduction, New York, v. 80, n. 6, p. 1272-1281, jun. 2009.

LOUREIRO, B.; ERENO, R. L.; FAVORETO, M. G.; PUPULIM, A. G.; FONTES, P. K.; TICIANELLI, J. S.; PINTO, R. F. P.; CASTILHO, A. C. S.; BARROS, C. M. Expression of androgen producing enzymes in low and high follicle count Nellore cows. Animal Reproduction, Amsterdam, v. 9, n. 3, p. 458-458, jul./sept. 2012.
MOSSA, F.; WALSH, S. W.; BUTLER, S. T.; BERRY, D. P.; CARTER, F.; LONERGAN, P.; SMITH, G. W.; IRELAND, J. J.; EVANS, A. C. Low numbers of ovarian follicles $>/=3 \mathrm{~mm}$ in diameter are associated with low fertility in dairy cows. Journal of Dairy Science, Champaign, v. 95, n. 5, p. 2355-2361, may 2012.

MURASAWA, M.; TAKAHASHI, T.; NISHIMOTO, H.; YAMAMOTO, S.; HAMANO, S.; TETSUKA, M. Relationship between ovarian weight and follicular population in heifers. Journal of Reproduction and Development, Cambridge, v. 51, n. 5, p. 689-693, oct. 2005.

PONTES, J. H.; MELO STERZA, F. A.; BASSO, A. C.; FERREIRA, C. R.; SANCHES, B. V.; RUBIN, K. C.; SENEDA, M. M. Ovum pick up, in vitro embryo production, and pregnancy rates from a large-scale commercial program using Nelore cattle (Bos indicus) donors. Theriogenology, Stoneham, v. 75, n. 9, p. 16401646, jun. 2011.

PONTES, J. H.; SILVA, K. C.; BASSO, A. C.; RIGO, A. G.; FERREIRA, C. R.; SANTOS, G. M.; SANCHES, B. V.; PORCIONATO, J. P.; VIEIRA, P. H.; FAIFER, F. S.; STERZA, F. A.; SCHENK, J. L.; SENEDA, M. M. Largescale in vitro embryo production and pregnancy rates from Bos taurus, Bos indicus, and indicus-taurus dairy cows using sexed sperm. Theriogenology, Stoneham, v. 74, n. 8, p. 1349-1355, nov. 2010.

SANTOS FILHO, A.; OLIVEIRA, M. A.; CALDAS, J. G.; LIMA, P. F.; DONATO, I. V. Ovarian follicular dynamics of five-eighths Girolando cows. Reproduction of Domestic Animals, Malden, v. 36, n. 3-4, p. 207-210, aug. 2001.

SARTORI, R.; BASTOS, M. R.; WILTBANK, M. C. Factors affecting fertilisation and early embryo quality in single- and superovulated dairy cattle. Reproduction, Fertility and Development, Collingwood, v. 22, n. 1, p. 151-158, 2010.

SATRAPA, R. A.; CASTILHO, A. S.; RAZZA, E. M.; PEGORER, M. F.; PUELKER, R.; BARROS, C. M.; Differential expression of members of the IGF system in OPU-derived oocytes from Nelore (Bos indicus) and Holstein (Bos taurus) cows. Animal Reproduction Science, Amsterdam, v. 138, n. 3-4, p. 155-158, may 2013.

SCHOPPEE, P. D.; ARMSTRONG, J. D.; HARVEY, R. W.; WHITACRE, M. D.; FELIX, A.; CAMPBELL, R. M. Immunization against growth hormone releasing factor or chronic feed restriction initiated at 3.5 months of age reduces ovarian response to pulsatile administration of gonadotropin-releasing hormone at 6 months of age and delays onset of puberty in heifers. Biology of Reproduction, New York, v. 55, n. 1, p. 87-98, feb. 1996. 
SILVA-SANTOS, K. C.; SANTOS, G. M.; KOETZ JUNIOR, C.; MOROTTI, F.; SILOTO, L. S.; MARCANTONIO, T. N.; URBANO, M. R.; OLIVEIRA, R. L.; LIMA, D. C.; SENEDA, M. M. Antral follicle populations and embryo production--in vitro and in vivo-of Bos indicus-taurus donors from weaning to yearling ages. Reproduction of Domestic Animals, Malden, v. 49, n. 2, p. 228-232, apr. 2014a.

SILVA-SANTOS, K. C.; SILOTO, L. S.; SANTOS, G. M.; MOROTTI, F.; MARCANTONIO, T. N.; SENEDA, M. M. Comparison of antral and preantral ovarian follicle populations between Bos indicus and Bos indicus- taurus cows with high or low antral follicles counts. Reproduction of Domestic Animals, Malden, v. 49, n. 1, p. $48-51$, feb. 2014 b.

SINGH, J.; DOMINGUEZ, M.; JAISWAL, R.; ADAMS, G. P. A simple ultrasound test to predict the superstimulatory response in cattle. Theriogenology, Stoneham, v. 62, n. 1-2, p. 227-243, jul. 2004.

WALSH, S. W.; WILliAMS, E. J.; EVANS, A. C. A review of the causes of poor fertility in high milk producing dairy cows. Animal Reproduction Science, Amsterdam, v. 123, n. 3-4, p. 127-138, feb. 2011. 
